Article

\title{
Towards a Conceptual Framework for Struggles over Democracy in Backsliding States: Gender Equality Policy in Central Eastern Europe
}

\author{
Andrea Krizsan ${ }^{1}$ and Conny Roggeband ${ }^{2, *}$ \\ ${ }^{1}$ Center for Policy Studies, Central European University, 1051 Budapest, Hungary; E-Mail: krizsana@ceu.edu \\ 2 Department of Political Science, University of Amsterdam, 1018 VW Amsterdam, The Netherlands; \\ E-Mail: c.m.roggeband@uva.nl \\ * Corresponding author
}

Submitted: 9 February 2018 | Accepted: 14 June 2018 | Published: 14 September 2018

\begin{abstract}
Trends of de-democratization across Europe and the Americas are emerging, along with opposition to gender equality and threats to previous gender equality policy gains. Yet de-democratization has been barely analysed through the lens of gender equality, and so far, efforts to systematically analyse the implications for inclusive democracy and the representation of gender interests are lacking. Backsliding in gender policies, and new forms of feminist engagement with hostile states and publics, also raise new challenges to the literature on gender and politics. In this article we explore gender equality policy backsliding in fragile democracies. Backsliding and de-democratization processes in these contexts pose a series of important challenges to how we have thought about gender policy change in progressive, mainly Western democratic contexts until now. We propose a conceptual framework discussing these two conceptually interesting realms: backsliding in gender equality policies, and feminist responses to backsliding. We illustrate our framework with empirical observations from four backsliding or temporarily backsliding Central and Eastern European countries: Croatia, Hungary, Poland and Romania. With our article we aim to contribute to the understanding of gendered aspects of de-democratization both in gender and politics literature and in mainstream democratization literature.
\end{abstract}

\section{Keywords}

backsliding; Central and Eastern Europe; democracy; feminism; fragile democracy; gender; resilience; women's movements

Issue

This article is part of the issue "The Feminist Project under Threat in Europe", edited by Mieke Verloo (Radboud University, The Netherlands) and David Paternotte (Université Libre de Bruxelles, Belgium).

(C) 2018 by the authors; licensee Cogitatio (Lisbon, Portugal). This article is licensed under a Creative Commons Attribution 4.0 International License (CC BY).

\section{Introduction}

The last decades since the 1995 Beijing Women's World Conference can be seen globally as years of significant progress in the adoption of gender equality policies in fields as diverse as political participation, labour markets, care and violence against women. Yet, this progress is currently under attack. Trends of backsliding and dedemocratization have emerged across Europe and the Americas, mainly coinciding with the recent economic and financial crisis. We see articulated opposition to gender equality and threats to previous gender equality policy gains. This raises new challenges for the literature on gender and politics. Women's rights are particularly vulnerable in fragile and nascent democracies where such rights have been more recently established and where the space of civil society actors to defend such rights is limited and even shrinking (Baker et al., 2017; Carothers \& Brechenmacher, 2014; Rutzen, 2015). While significant attention has been devoted to democratic backsliding (Bermeo, 2016; Greskovits, 2015), there is a striking lack of research into the gendered aspects and implications of democratic backsliding.

In this article we propose a conceptual framework to analyse and reveal the consequences of these processes for inclusive democracy. The quality of democracy can 
be assessed on the degree of its inclusiveness and representativeness of societal interests, and more specifically its responsiveness to women's interests (McBride \& Mazur, 2010, p. 10). We ask: what does backsliding mean for gender equality policies and what are its implications for women's rights? How do feminists respond to and resist backsliding? And how can we capture the impact of feminist resistance in changing largely hostile contexts? To develop our conceptual framework we use empirical illustrations from the Central and Eastern European (CEE) region, which has been at the forefront of backsliding in gender equality policies in recent years (Kikas, 2016; Krizsan \& Roggeband, 2018; Selewa, 2016). We focus on Croatia, Hungary, Poland and Romania, which exhibit particularly strong but also diverse patterns of retrenchment: some radical, others incremental, some ongoing over long periods of time, others stopped by impressive patterns of civil society resistance (Kikas, 2016; Krizsan \& Roggeband, 2018; Selewa, 2016). We do not use our empirical cases to explain causality in a neat comparative model, but rather to stipulate patterns of backsliding where those emerge, and feminist responses to it. The patterns we witness may not only be typical for the region, and so could provide important lessons for understanding mechanisms of gender equality policy backsliding and responses to it in other parts of Europe and beyond ${ }^{1}$.

In the first part of the article we develop a conceptual framework to map the implications of current attacks on gender equality and women's rights on gender equality policies and political representation of women. Across the CEE region we see official political discourses changing from positions that were either largely supportive or silent on gender equality to openly challenging previously adopted and accepted gender equality policy positions (Krizsan \& Roggeband, 2018). Do such discursive attacks translate to policy dismantling? We build on public policy literature on policy dismantling, recent work on democratic backsliding, and studies in gender and politics explaining progress in gender equality policies to explore the conditions of decline and reversal of gender equality policies and their impact on the political representation of women.

In the second part of the article, we turn to the drivers of gender equality policies, namely women's rights activists (Beckwith, 2013; Htun \& Weldon, 2012; McBride \& Mazur, 2010), to ask: how does democratic backsliding affect the voice and standing of women's rights advocates? The participation and inclusion of women in the realm of politics are key to struggling against persisting inequalities. Fair and free elections can only serve this to a limited extent. For underrepresented groups, such as women, inclusive democracy also means empowerment and inclusion in policy and governance processes through civil society organizations represent- ing the voice of such groups. The widely documented closure of civic space (Baker et al., 2017; Carothers \& Brechenmacher, 2014) disempowers women's organizing. It thus makes it difficult for women to prevent the reversal of rights and dismantling of gender equality policies, and to contest the promotion of legislation and policies detrimental to gender equality. We use empirical observations from women's activism in the four backsliding CEE countries to explore patterns of response and resistance to increased state hostility.

\section{Backsliding of Gender Policies}

Democracy scholar Bermeo defines democratic backsliding as the "state-led debilitation or elimination of any of the political institutions that sustain an existing democracy" (2016, p. 5). Greskovits takes a less institutional approach by defining it as a "destabilization or even a reversal in the direction of democratic development" (Greskovits, 2015, p. 28). Both view backsliding as an ongoing, gradual process rather than a turning point that can be clearly identified in time. Others link democratic backsliding to a cultural backlash against ongoing social changes including progress in gender equality (Fomina \& Kucharczyk, 2016; Norris, 2016). Yet, most dedemocratization writings concentrate on more general institutional aspects of democracy and pay less attention to backsliding in terms of representativeness and inclusiveness of democracies (Tilly, 2007; Walby, 2015). In order to capture these dimensions there is a need for a more comprehensive conceptualization of democratic backsliding that takes into account regression in gender representativeness. We suggest that Pitkin's (1967) classic distinction between descriptive, substantive and symbolic representation can best capture the dimensions of inclusive democracy and serve as a useful starting point to comprehensively conceptualize gender equality backsliding. Descriptive representation can be captured through inclusive policy processes, substantive representation can be analysed by looking at policy content, while symbolic representation can be analysed through discursive construction of women's and gender equality issues by critical political actors. We use various bodies of literature to develop a concept of backsliding along these three dimensions.

Policy literature mainly operates on the assumption of institutional stability and incremental policy change, and there is far less extensive discussion on policy dismantling and reversals (Bauer, Green-Pedersen, Héritier, \& Jordan, 2012; Bauer \& Knill, 2014). More recent literature focuses on policy dismantling but neglects to look at two aspects that are important for gender policies: changes in inclusive policy processes, and changes in symbolic representation. Bauer et al. (2012) define policy dismantling as:

\footnotetext{
${ }^{1}$ Data for our analysis comes partly from our previous comparative project focusing on the development of policies against violence against women in these countries. This data is complemented with desk and media research and interviews with feminist activists and femocrats conducted in the four countries.
} 
A change of a direct, indirect, hidden or symbolic nature that either diminishes the number of policies in a particular area, reduces the number of policy instruments used and/or lowers their intensity. It can involve changes to these core elements of policy and/or it can be achieved by manipulating the capacities to implement and supervise them. (p. 4)

Bauer et al. conceptualize dismantling along two dimensions: policy density and intensity. Density refers to changes in the number of policies in a given policy field, while intensity refers to the depth of intervention (2012, p. 34). Qualitative erosion of policies such as reframing and/or co-optation of content (Krizsan \& Roggeband, 2018; Lombardo, Meier, \& Verloo, 2009; Stratigaki, 2005) are particularly fundamental problems in the field of gender policies and could be seen as an aspect of changes in policy intensity.

In recent years, two strands of literature have developed that address backsliding in the realm of gender equality. Firstly, increased (discursive) opposition to gender equality mobilized by a broad range of conservative, nationalist and religious actors has been widely discussed (Kovats \& Poim, 2015; Kuhar, 2015; Kuhar \& Paternotte, 2017; Verloo, 2018). Explicit opposition to gender equality principles is a form of backlash that particularly challenges morality and sexuality aspects of gender equality through political statements and in some instances also through policy proposals. We see here backsliding in symbolic representation of gender equality.

The second strand of literature focuses on the politics and policy reversals following the economic crisis in Europe and discusses how the crisis has strengthened neoliberal trends and has led to backsliding in the context of gendered austerity measures (Bettio et al., 2012; Kantola \& Lombardo, 2017; Walby, 2015). Austerity measures have resulted in increasing social inequality and discrimination against women (Kantola \& Lombardo, 2017; Karamessini \& Rubery, 2013). While anti-discrimination policies and other legal instruments remained in place, cuts were prominent in budgets and institutional frameworks, and have led to a decreased inclusion of women's groups. Backsliding is captured here both in terms of substantive and descriptive representation.

These bodies of literature point both to stability and to vulnerability in terms of institutional frameworks, implementation and accountability, and to discursive threats to gender equality objectives. They also indicate issue specificity within the wider range of gender policy issues. It has been argued earlier that various gender equality policy sub-issues are characterized by different policy dynamics, including diverse patterns of actor dynamics, different dynamics of political representation, institutional friction and veto points, and that this may result in differences in policy attention (Annesley, Engeli, \& Gains, 2015; Htun \& Weldon, 2012; McBride \& Mazur, 2010). Morality issues such as sexual and reproductive rights are particularly sensitive to contestation (Kovats
\& Poim, 2015; Kuhar, 2015; Kuhar \& Paternotte, 2017). Class-based issues emerge as a topic of political struggle in the context of the economic and financial crisis (Bettio et al., 2012; Kantola \& Lombardo, 2017; Karamessini \& Rubery, 2013; Krizsan \& Zentai, 2017). Legal frameworks embedded in European Union (EU) norms may be less prone to backsliding.

While these two strands of literature provide important insights, there is a lack of systematic analysis of the implications of discursive attacks on gender equality policies, and the scope of policy backsliding. In the next section we develop a conceptual framework for analysing gender policy backsliding. We combine ideas on policy dismantling and democratic backsliding with ideas about discursive opposition to gender equality, thus covering aspects of backsliding in terms of descriptive, substantive and symbolic representation.

\subsection{A Conceptual Framework for Analysing Gender Policy Backsliding}

Certain patterns of backsliding in gender policies emerge, but it remains unclear how systematic these patterns are and what they imply for inclusive democracy and the representation of gender, particularly in the context of fragile democracies. Better conceptual work is needed to bring various dimensions of backsliding together in a sound conceptual framework (Goertz \& Mazur, 2008).

Gender equality policy progress is often measured along two criteria: the framing of policy content along the lines of women's movement framing, and an inclusive policy subsystem integrating women's movement actors (Krizsan \& Roggeband, 2018; McBride \& Mazur, 2010). We complement this framework with other elements from the previously discussed literature. From the policy dismantling literature, we take the observation that policy termination is rare and that we need more gradual measurements of change towards erosion or dismantling. We also borrow the idea of backsliding as a process rather than a fixed turning point in time. From the gender and politics literature we take the emphasis on framing of policies, the erosion of accountability mechanisms, and the symbolic importance of openly oppositional policymaker discourses which delegitimize gender equality policies and represent gender issues in exclusionary ways. We propose to define backsliding in the field of gender equality policies with reference to the substantive normative content of gender equality as a benchmark. But we see gender equality as an empty signifier, the meaning of which may differ depending on political, social and cultural contexts (Lombardo et al., 2009). To use a substantive but contextualized approach, we define backsliding as states going back on previous commitments to gender equality norms as defined in their respective political contexts.

We operationalize policy backsliding in the field of gender equality along four complementary dimensions which also correspond to symbolic, substantive and de- 
scriptive aspects of representation (Pitkin, 1967): 1) discursive (de)legitimisation of gender policy objectives; 2) dismantling and reframing existent policies; 3 ) undermining implementation; and 4) erosion of accountability and inclusion mechanisms. This multi-dimensional framework allows us to examine how backsliding patterns vary across specific gender equality issues and across countries, while it also allows for a gradual rather than a dichotomous approach to backsliding (Goertz \& Mazur, 2008). Below we elaborate on each dimension and provide some empirical illustrations of it.

\subsubsection{Discursive Delegitimization of Gender Equality Policies}

A widely noted and prominent aspect of policy backsliding is changes in official political discourses from positions largely supportive or silent on gender equality to statements that openly challenge gender equality objectives, often going in opposition to a country's formally adopted and accepted policy positions (Krizsan \& Roggeband, 2018). Oppositional statements on gender equality made by high-level political actors who are part of the governing structure or governing political party question the legitimacy of gender equality as a goal and discredit existing policies. Backsliding here means increasingly hostile policy processes, where anti-gender equality positions negatively influence how policies are perceived and implemented.

A particularly strong example of discursive opposition is in Poland where, since the end of 2015, the populist right-wing government has used a strong antigender equality rhetoric in which 'gender ideology' features as a major threat to Polish society and Catholic family values. Statements that challenge gender equality are issued on a regular basis by government officials. Similar statements are also issued occasionally by government officials in Croatia (Kikas, 2016), and more recently in Hungary as well (Felix, 2015).

\subsubsection{Policy Dismantling and Reframing}

Backsliding may take the form of dismantling existing policies. However, more often changes take place by amending policies so that their priorities or objectives change. Backsliding may occur when a policy problem is radically reframed so that the new frame contrasts with gender equality meanings or allows for contrasting interpretations. Reversal of policy frames may also happen when gender-sensitive issues present in the diagnostic or prognostic frames of policy regimes disappear. Reframing existent policies from targeting equal opportunities to, for example, protecting family values or refocusing care around the family unit, while allowing for their continued operation, is a pattern that can be observed to reverse progress in gender equality policy regimes (Krizsan \& Zentai, 2017). An example of this is Croatia where a new Criminal Code adopted in 2011, and entering into force on 1 January 2013, removed the specific prohibition of "violent, abusive, or particularly insolent conduct" within a family (Article 215A). Family relations were kept only as an aggravated circumstance for other, more severe criminal offences, such as injuries, severe and extremely severe injuries, threat or coercion (Manjoo, 2013). Repealing these specific domestic violence provisions means that domestic violence offences can now only be prosecuted as misdemeanours, as the coercive control element is no longer part of the Criminal Code (Advocates for Human Rights \& Autonomous Women's House, 2015). In addition, a new Family Law was drafted to "support traditional family values" (Stubbs, 2016). The Law contains provisions that oppose gender equality and disregard the power dynamics in domestic violence, such as mandatory mediation in divorce cases, serious consequences for a parent who "refuses to cooperate" in raising children, and fines for parents who prevent contact with children. Furthermore, the term "domestic violence" was replaced with the ambiguous "highly conflictual relations". The new Criminal Code and the Family Law brought the family protection framing to the level of statute. The Constitution of Croatia was also amended following a popular referendum in 2013 initiated by conservative actors, but tacitly supported by the government, to limit family and marriage rights to heterosexual couples.

\subsubsection{Undermining Implementation Arrangements}

Reversal and dismantling of policies can also take place at the level of the institutional design of a policy regime. Institutional design may include mechanisms such as coordinating authorities, intergovernmental and other partnerships, networks of private and public entities, and contractual relationships. Policies can be abandoned by not continuing their ongoing programmatic processes or made impossible by defunding. The literature about the gendered implications of austerity measures points to stalling strategic programming processes, closing gender equality institutions or cutting funds that make their operation feasible (Bettio et al., 2012; Kantola \& Lombardo, 2017; Krizsan \& Zentai, 2017).

Dismantling of institutional arrangements is a relatively easy and low-key form of rolling back policies. One illustrative example is the Hungarian case where, starting from 2010, the Fidesz government dismantled most of the gender equality structures put in place under the previous government. The gender equality unit was closed and re-established with only two people on board, under the deputy state secretary for Family and Population Policy. This implied both a downsizing and reframing of gender equality policy objectives into family policy objectives. The consultative Gender Equality Council has not been convened since 2010. The implementation of the 2010 National Gender Equality strategy was immediately stalled after the elections, and no activities were launched under it by the new government. Funds were 
diverted from gender equality objectives towards objectives opposing it. For example, money coming from the EU'S PROGRESS fund was used for an anti-abortion campaign in ways that were challenged by EC Commissioner Viviane Reading (Euractiv, 2011).

\subsubsection{Erosion of Inclusion and Accountability Mechanisms}

Accountability processes especially by means of inclusive policy making and consultation processes including women's rights advocates are a critical element in the field of gender policy progress (Ferree \& Gamson, 2003; McBride \& Mazur, 2010). Policy inclusion is seen by gender and politics literature as a policy outcome in itself, but also as a factor securing more equitable representation for gender interests. As such, reversal on policy inclusion has consequences for the backsliding of gender policies. Gender equality policies may be undermined if women's rights advocates are not meaningfully involved in policy processes beyond agenda-setting (Krizsan \& Roggeband, 2018). Essential elements identified in backsliding in the context of the economic crisis are the breaking of accountability loops and de-democratizing of policy-making processes (Kantola \& Lombardo, 2017; Krizsan \& Zentai, 2017; Walby, 2015). The most direct challenge is dismantling formal consultation structures such as councils or committees established for sustainable communication between civil society groups representing gender equality and governments. Formal consultation mechanisms have been particularly hit in Hungary, Romania and Poland. In Romania, even parliament was side-lined by decision-making through executive orders. Formal consultation processes have also been curtailed by selective access to consultation based on government preferences. Selective inclusion of civil society actors has led to the exclusion of rights-based groups from consultation and their replacement by alternative groups in Hungary (Krizsan \& Zentai, 2017), Croatia and Poland.

\subsection{Dismantling Patterns and Strategies}

The advantage of using a multi-dimensional framework is that it enables a detailed and systematic analysis of various dimensions of backsliding across countries, and specific gender issues. In general, we expect that backsliding will affect some policy areas more than others, i.e., backsliding will be more prominent along some of our four dimensions in some gender policy issues. In addition to this, we expect to find variations between countries related to specific strategies that politicians may employ in each context. Bauer et al. (2012) point to four different dismantling strategies. Active dismantling is the most visible form, where politicians clearly and openly express their wish to dismantle or end a policy and take actions to do this. Secondly, and in contrast to active dismantling, politicians may claim their intention to dismantle, but these declarations are not acted upon or serve some other objective, and hence remain symbolic. Thirdly, dismantling decisions may be moved to another political arena, by manipulating the organizational or procedural basis of a policy or transferring the policy to another government level or to a (newly established) agency. Finally, the subtlest strategy is dismantling by defaults, where governments simply do not enact or execute policies, which may lead to policy extinction. Change is made without formal decision; it has little visibility but may affect policy instruments, institutional structures, or accountability mechanisms. Bauer et al. propose that dismantling strategies depend on the political ideology and preference of politicians, but are also situational, so depend on available opportunities and constraints, and public and political support or opposition.

The typology is a useful starting point to think about dismantling strategies, but we propose to add some more elements to it. First, we consider the pace of dismantling as an additional essential element. Processes of dismantling can be rapid, which is often related to drastic cuts, or more incremental, which comes from lowkey, small, "under the radar" forms of dismantling. Second, we consider that strategies will be issue-specific and entail different rationales and justification. We contend that the type of dismantling strategy chosen to roll back gender equality policies creates specific opportunities and constraints for feminist activists to respond or resist. Low key, incremental processes of policy backsliding remain largely invisible to the wider public and may therefore be more difficult to address than radical and drastic cuts openly announced by governments. Visible forms of dismantling are more likely to generate protest from a wider public and help activists to orchestrate massive protests to oppose government plans. Yet, feminist counter-strategies also depend on the extent of direct hostility or repression. This is a point that is left undiscussed in the policy dismantling literature and where we need social movement literature to better understand opportunities and constraints to respond to and/or struggle against policy dismantling.

\section{Backsliding States and Feminist Resilience}

The emergence of openly hostile and closing states presents new challenges to women's rights groups in the CEE region. Along with Ferree and Mueller (2004) we propose the use of an open and broad definition of women's movements as mobilizations based on appeals to women as a constituency, and thus as an organized strategy. With them we define feminism as the broad goal of challenging and changing unequal gender relations: "whether or not individuals or groups choose to call themselves feminist, their goal of empowering women should be considered feminist" (2006, p. vii). This open framework allows an examination of the different forms and faces of women's organizing for gender equality within and across countries. 
Hostile states can hinder movement actors in stepping up against gender policy backsliding. During the democratization period, women's rights groups strongly relied on transactional activism (Krizsan \& Roggeband, 2018; Tarrow \& Petrova, 2007) rather than grassroots activism to pursue gender policy change, meaning that they focused on networking with other organizations, including state actors. It is through strategically chosen patterns of engagement with the state and with other civil society actors that gender policy progress could take place across the region (Krizsan \& Roggeband, 2018). Movements with diverse organizational patterns that combined insider and outsider strategies to engage the state were the most successful in gendering adopted policies (Krizsan \& Roggeband, 2018). The increased hostility towards critical civil society organizations in general, and towards women's rights organizations in particular, blocks earlier successful strategies of engaging the state. Networking with state actors is marginalized or becomes impossible. Preliminary evidence suggests that women's organizations are side-lined, persecuted or co-opted by governments. This is in line with findings of other studies on civil society and protests in backsliding or (semi-)autocratic states.

\subsection{Government Hostility to Women's Organizations}

Governments moving towards authoritarianism often use methods of control to suppress civil society organizations they perceive as threatening. These methods may include the creation by the state of seemingly civic organizations, often referred to as GONGOs, to influence the realm of civil society in a way that directly supports state power (Doyle, 2017); co-optation by using the reliance of independent organizations on state funding or cooperation to control their activities; and repressive or even violent actions ranging from disproportionate auditing as a means of control to policing and violence, which limit and disempower organizations (Baker et al., 2017). These three forms of state hostility are also visible in the CEE region and limit the space for women's organizations to cooperate with the state or act as critical outsiders.

In Hungary, Poland and Croatia we find governmental strategies to defund women's rights organizations and redirect public funds to alternative, governmentfriendly women's organizations. Women's rights groups in Hungary have seen an unprecedented absence of funding under the Fidesz government, including the blocking of funding by non-state donors such as the Norwegian Civil Grants (TASZ, 2016). In the meantime, funding has been increasingly directed towards conservative women's groups and family protection groups. In 2013 an alternative coalition (Association of Hungarian Women) was launched to challenge the place of the Hungarian Women's Lobby in the European Women's Lobby and to delegate a representative to the European Institute for Gender Equality. Similarly, in Poland, government officials like the Plenipotentiary for Civil Society and Equal Treatment have stated that they seek to develop a cadre of "conservative" NGOs that can focus on topics such as women's and family issues, discrimination, and refugees/migration from a traditional perspective. The government created a competing organization, the Confederation of Non-Governmental Initiatives of Poland, that will presumably become the coordinating body of the new community of government-organized NGOs (Human Rights First, 2017, p. 16). In Croatia, the women's movement's insider status has been severely limited since 2011, when actors and rhetoric opposed to gender equality strengthened and governmental allies disappeared. Women's groups are now rarely invited to the negotiation table to discuss policy changes, though remain external critics to the process (Krizsan \& Roggeband, 2018). Family protection, men's rights and other conservative groups have infiltrated consultative mechanisms, frequently blocking policy progress. Previously successful patterns of cooperation between women's rights groups and the state have faltered.

Co-optation of women's rights groups has been particularly used in contexts where formalized state funding has been available for services provided by women's rights groups. In Croatia tension emerged between women's rights groups around issues of autonomy from versus cooperation with the state, funding, and definitions of domestic violence back in 2005 (Krizsan \& Roggeband, 2018). This tension was overcome, to some extent, in domestic violence policy mobilizations during 2008. After 2008, however, the movement fragmented once again. Leadership issues also struck the initially successful Women's Network. It is this dense (Mamula, Vukmanić, Zore, Stanić, \& Hojt, 2010) yet fragmented women's movement that had to face the increasingly hostile context and state closure. One strategy used by the state to restrain women's groups, de-fund them or coerce them into cooperation was to tender funding available for services for victims of domestic violence. Tendering needed extremely high investment of resources by women's groups as well as conforming to complex protocols that were often contrary to feminist principles (Minnesota Advocates for Human Rights, Autonomous Women's House, Zagreb, \& Bulgarian Gender Research Foundation, 2012). Conditionality imposed on women's groups and resulting patterns of dependency have long been discussed (Alvarez, 1999; Ghodsee, 2004) in relation to neoliberal states. A move towards replacing previously earmarked state funding with tendering is a relatively recent phenomenon in Central and Eastern Europe, but has gained new relevance as it has emerged together with state hostility to and closure towards women's rights groups.

Repressive actions against women's rights groups can range from regulatory tools such as excessive auditing and surveillance to more violent and repressive tools such as police searches, raiding of offices, holding computers or even arrests of activists. They limit activism both by means of threat but also by demanding unnec- 
essary and mostly unavailable resources for handling excessive auditing. From 2013, waves of auditing and raids took place in Hungary against several rights NGOs (women's rights, LGBT, civil rights) funded by the Norwegian Civil Fund. Auditing procedures ran for years and were closed down without any findings of irregularity (TASZ, 2016). In a similar vein, in 2017 the Polish government began a financial review of targeted "liberal" NGOs, requiring many to produce documents in an audit-like procedure for the first time. It ordered several organizations to return grant money, while withholding funding from others (Human Rights First, 2017, p. 5). The police raid on the offices of the main women's rights organizations in several Polish cities in October 2017 also exemplifies this kind of threat and repression. The timing of the raids, one day after women's organizations had staged anti-government marches to protest the country's restrictive abortion law, suggest they are a tool of intimidation (The Guardian, 2017).

\subsection{Movement Resistance and Survival}

Emergent state hostility towards women's rights advocates has consequences for how women's movements can maintain their role in promoting democratic representation of women's interests. Movement capacity and movement strategies of engagement with the state are dimensions we previously took (Krizsan \& Roggeband, 2018) to conceptualize movement influence on policymaking. Both dimensions are affected by the forms of state hostility discussed above. How do women's movements respond to this? Social movement literature is remarkably silent about movement strategies under conditions of democratic backsliding. Literature on responses to the economic crisis points to instances of demise and failure of movements, but in some cases also to revival and maturing and the emergence of innovative forms of resistance (Kantola \& Lombardo, 2017; Krizsan \& Zentai, 2017). Feminist resilience and responses to backsliding will on the one hand depend on the capacity of women's movements and their strategies of state engagement before backsliding, and on the other hand on the modes and strategies of policy dismantling used by governments, to which movements react. Movements may react differently to active and symbolic dismantling than to dismantling by default.

Empirically, we see divergent patterns of feminist resistance to policy backsliding and state hostility emerge in the four countries, and various ways of feminist coping with the context of hostility to gender and dedemocratization. We identify three strategies: disruptive protest, new patterns of coalition building, and abeyance and demise.

\subsubsection{Turn to Grassroots and Disruptive Protest}

Women's movements traditionally use less obtrusive persuasive strategies, including participation in consultation processes or lobbying policymakers (Htun \& Weldon, 2012). Yet, in the context of state hostility and closure, more disruptive repertoires are required. These may result in more radically framed claims that are less open to negotiation and also require different movement capacities and infrastructure (Andrews, 2001). The strength and capacity of movements before the period of backsliding will make a difference to whether such capacity is available. Movements with diversified capacities (Andrews, 2001) might be in a better position to turn to confrontational strategies.

The capacity and resilience of the Polish women's movement is well illustrated by the massive protest against the government's proposal for even more restrictive abortion regulations in October 2016 (Davis, 2016), which ultimately led to the withdrawal of the proposal. It also demonstrates the ability to successfully connect feminist issues to wider democracy and human rights concerns and mobilizations. Revival and diversification of the Romanian women's movement and its strategies around the time of the economic crisis (Popa, 2015) is another example of resilience. New actors-including young feminists, professional women, as well as minority women's groups, in particular Roma women's advocates-entered the field of women's rights activism. This sparked new debates that engaged more radically with feminism and introduced more disruptive forms of activism.

\subsubsection{New Patterns of Coalition Building}

In the contexts of de-democratization, gender equality has come under attack together with other democratic values, human rights and rights of other vulnerable groups. These common external threats may forge new coalitions (Van Dyke \& McCammon, 2010) and contribute to overcoming divisions (Borland, 2010). Women's movements in CEE countries were rarely part of democratization movements and good working relations with other rights groups are the exception rather than the rule (Krizsan \& Roggeband, 2018). In Hungary, links between the women's movement and wider democratization processes and protests were very weak throughout the last decades and remained incidental even in the context of anti-democratic threats from the government. The women's movement remained largely disconnected from wider human rights and democratization protests; they were neither invited to join nor were interested in joining these platforms. Further, women's rights claims were rarely backed by these groups, except for some support from international rights groups, such as Amnesty International or Human Rights Watch.

Romanian mobilization in 2012 and Polish protests in 2016 show the importance of connecting women's rights-related protests to wider pro-democracy political protests in order to prevent the erosion and reversal of existing gender equality achievements during this continuing wave of de-democratization in the region. In Poland the protest against restricting abortion extended well be- 
yond feminist constituencies, thus integrating feminist claims into a wider pro-democracy agenda. In Romania, a coalition with diverse rights groups and integrating women's rights in the wider pro-democracy protests strengthened feminist claims and facilitated policy success in blocking further backsliding and adopting new progressive legislation on domestic violence (Krizsan \& Roggeband, 2018). Thus, the politicization of women's rights as an integral part of democratic achievements to be defended-and not just by women's rights groupsemerges as a successful strategy in the Romanian and the Polish cases.

\subsubsection{Abeyance and Demise}

While threat and opposition can reinvigorate and strengthen resistance, if it is systematic and long term, it may incapacitate weaker and more institutionalized movements. Abeyance (Taylor, 1989) is a response that can emerge in such cases. Abeyance is like a last resort, when a movement is barely able to openly challenge the state or function as usual. It is a state of survival in which a social movement manages to sustain itself and mount a challenge to authorities in a hostile political and cultural environment (Taylor, 1989). Abeyance structures promote movement continuity by sustaining organizational infrastructure from which a new protest wave may emerge in a different political environment. A move away from political activism towards academic feminism, organizing workshops and small group discussions is also a strategy that may be used, and is a familiar ground for many women's movements in CEE.

We observe a decline and even demise of women's movements, which needs to be analysed more systematically. In 2016, the state of the previously weak and underfunded Hungarian women's movement organizations can be characterized as abeyance. Hungary had few women's movement organizations, and these were mainly based on highly educated, elite activists and primarily, though not exclusively, centralized in Budapest. Though their activities were relatively diversified they were rarely able to mobilize large protests and could not establish long-term alliances with state actors. The state has never provided meaningful financial support for women's groups, neither at the national nor municipal level, and foreign funding has also been weak (Krizsan \& Roggeband, 2018). The right-wing populist Fidesz government blocked communication almost entirely, cut state funding, and restrained foreign funding. This ultimately forced most women's groups out of business by 2016 and limited resistance to a few isolated activists, academics and MPs.

\section{Conclusion}

In this article we have aimed to contribute to recent debates on de-democratization. We argue that gender aspects of de-democratization processes are generally overlooked and their inclusion is crucial for a more comprehensive understanding of the consequences of democratic backsliding for women but also for other marginalized groups. Along with McBride and Mazur we claim that the quality of democracy can be assessed on the degree of inclusiveness and representativeness of societal interests, and more specifically responsiveness to women's interests (2010, p. 10). We propose a conceptual framework to capture the implications of recent attacks on gender equality for policy and for women's rights advocacy, and more generally for inclusive democracy and the representation of women in politics. To this end we use Pitkin's (1967) distinction between descriptive, substantive and symbolic elements of representation. We propose two arenas where gendered aspects of de-democratization can be captured: backsliding of gender policies, and changes in feminist engagement with the political realm.

To map backsliding in gender policies we elaborate a conceptual framework starting from policy change and dismantling literature and gender and politics literature. We distinguish four dimensions of gender equality policy backsliding: discursive de-legitimization of gender policies, policy dismantling, undermining implementation, and erosion of inclusion and accountability mechanisms. We see these dimensions as interrelated and complementary. Just like descriptive, substantive and symbolic representation (Childs \& Lovenduski, 2013), these dimensions need to be seen together to capture the full spectrum of gender policy backsliding and its implications for the political representation of women. We propose that backsliding needs to be understood to mean more than just the removal or dismantling of policies, to include subtle and gradual reframing, or the undermining of implementation capacities such as institutions, planning or budgets. For backsliding to occur it is not necessary that all dimensions are present simultaneously. Backsliding may be present in only one dimension, and not in others. We contend that presence of reversal in one aspect can be expected to lead to further backsliding in the policy regime. Discursive de-legitimization of policies, or broken accountability, may ultimately result in a change of policy framing or institutional arrangements. Based on our empirical observations we expect that delegitimization is a key element in current processes of backsliding, and formal policy consequences may not follow directly and immediately. Backsliding appears to affect implementation and institutional arrangements that support policies, and consultation mechanisms involving women's rights advocates. A systematic analysis, applying our framework, is necessary to know what dimensions are most affected and what specific gender equality policy issues are most vulnerable to which aspects of backsliding.

The other arena where gendered aspects of dedemocratization can be identified is engagement of feminist activism with the political arena. Our framework suggests that backsliding mainly leads to decreased inclu- 
sion of women's rights advocates in policy processes. For women, and other groups that are underrepresented in formal politics, alternative forms of representation such as consultation and inclusive policy processes are crucial. We see this space declining through marginalization or exclusion from consultative platforms, decreased funding or outright persecution of groups. Yet, backsliding and attacks on gender equality could also have reinvigorating effects on feminist mobilization. Diversification of organizational forms, mobilization strategies and funding may be new forms of engagement. We argue that the blocking of institutional channels of representation through policy consultation forces feminists to seek other non-institutional channels like confrontational street protest. In particular, mass protests and building new inclusive coalitions are important tools to draw attention to the underrepresentation of women. More of these grassroots initiatives may also lead to new innovative forms of activism that might previously have been non-existent in the fragile democracies of the CEE region. At the same time, if movements are not able to generate such massive support they more likely turn to abeyance tactics.

Strategies of resistance will partly depend on the patterns of backsliding. Active dismantling of policies will more likely generate disruptive protests and wide coalitions of protest. Meanwhile, high levels of mobilization and active coalition work in ideologically inconsistent coalitions are difficult to sustain over the long term, in cases of incremental backsliding. Gradual and subtle forms of backsliding make feminist responses more difficult as they require evidence to pinpoint the change and communicating this in order to mobilize constituencies and bystanders. Also, gradual backsliding makes it necessary for movements to be able to sustain their activity over a longer time, while resources are declining.

Our framework for analysing women's movement resistances can show emerging possibilities for redemocratization by strong articulation of protest, and by forging new alliances. It also opens opportunities for identifying patterns of re-gendering or gendering democracy in certain cases where feminists failed on previous occasions. Research on feminist activism may inform analysis of activism of other marginalized groups in contexts of de-democratization.

\section{Acknowledgments}

This article benefitted from excellent comments during conference panels at the ECPG in Lausanne and the ECPR General Conference in Oslo. We would especially like to thank Isabelle Engeli, Mieke Verloo, Hege Skjeie, Birte Siim and Andrea Spehar. We would also like to thank Marianna Szczygielska, Leda Sutlovic and Andrea Sebestyen for their valuable inputs to the data collection process.

\section{Conflict of Interests}

The authors declare no conflict of interests.

\section{References}

Advocates for Human Rights, \& Autonomous Women's House. (2015). Croatia. Written statement dated June 12, 2015. Submitted to the 61st Session of the Committee on the Elimination of Discrimination against Women. Retrieved from http://tbinternet. ohchr.org/Treaties/CEDAW/Shared\%20Documents/ CRO/INT_CEDAW_NGO_CRO_20874_E.pdf

Alvarez, S. E. (1999). Advocating feminism: The Latin American feminist NGO 'Boom'. International Feminist Journal of Politics, 1(2), 181-209.

Andrews, K. T. (2001). Social movements and policy implementation: The Mississippi civil rights movement and the war on poverty, 1965 to 1971. American Sociological Review, 66(1), 71-95.

Annesley, C., Engeli, I., \& Gains, F. (2015). The profile of gender equality issue attention in Western Europe. European Journal of Political Research, 54(3), 525-542.

Baker, A., Boulding, C., Mullenax, S., Murton, G., Todd, M., Velasco-Guachalla, X., \& Zackary, D. (2017). Maintaining civic space in backsliding regimes (Research and Innovation Grants Working Papers Series). Boulder: University of Colorado.

Bauer, M. W., Green-Pedersen, C., Héritier, A., \& Jordan, A. (Eds.). (2012). Dismantling public policy: Preferences, strategies, and effects. Oxford: Oxford University Press.

Bauer, M. W., \& Knill, C. (2014). A conceptual framework for the analysis of policy change: Measurement, explanation and strategies of policy dismantling. Journal of Comparative Policy Analysis, 16(1), 28-44.

Beckwith, K. (2013). The comparative study of women's movements. In G. Waylen, K. Celis, J. Kantola, \& S. L. Weldon (Eds.), The Oxford handbook of gender and politics (pp. 385-410). New York, NY: Oxford University Press.

Bermeo, N. (2016). On democratic backsliding. Journal of Democracy, 27(1), 5-19.

Bettio, F., Corsi, M., D'Ippoliti, C., Lyberaki, A., Lodovici, M. S., \& Verashchagina, A. (2012). The impact of the economic crisis on the situation of women and men and on gender equality policies. Brussels, Belgium: European Commission.

Borland, E. (2010). Crisis as a catalyst for cooperation? Women's organizing in Buenos Aires. In N. Van Dyke, \& H. McCammon (Eds.), Strategic alliances: Coalition building and social movements. Minneapolis, MN: Minnesota University Press.

Carothers, T., \& Brechenmacher, S. (2014). Closing space. Democracy and human rights support under fire. Washington, DC: Carnegie Endowment for International Peace. 
Childs, S., \& Lovenduski, J. (2013). Political representation. In G. Waylen, K. Celis, J. Kantola, \& S. L. Weldon (Eds.), The Oxford handbook of gender and politics (pp. 489-513). Oxford: Oxford University Press.

Davis, C. (2016, October 5). Poland's abortion ban proposal near collapse after mass protests. The Guardian. Retrieved from https://www.theguardian. com/world/2016/oct/05/polish-government-performs -u-turn-on-total-abortion-ban

Doyle, J. L. (2017). State control of civil society organizations: The case of Turkey. Democratization, 24(2), 244-264.

Euractiv. (2011, June 17). EU funds used for Hungarian anti-abortion campaign. Euractiv. Retrieved from https://www.euractiv.com/section/justice-home-af fairs/news/eu-funds-used-for-hungarian-anti-abortion -campaign

Felix, A. (2015). Hungary. In E. Kovats, \& M. Poim (Eds.), Gender as symbolic glue. The position and role of conservative and far right parties in the anti-gender mobilizations in Europe (pp. 62-82). Budapest: FEPS-Foundation for European Progressive Studies.

Ferree, M. M., \& Gamson, W. A. (2003). The gendering of governance and the governance of gender. In B. Hobson (Ed.), Recognition struggles and social movements: Contested identities, agency and power (pp. 35-63). Cambridge: Cambridge University Press.

Ferree, M. M., \& Mueller, C. M. (2004). Feminism and the women's movement: A global perspective. In D. A. Snow, S. A. Soule, \& H. Kriesi (Eds.), The Blackwell companion to social movements (pp. 576-607). Malden, MA: Wiley-Blackwell Publishing.

Fomina, J., \& Kucharczyk, J. (2016). Populism and protest in Poland. Journal of Democracy, 27(4), 58-68.

Ghodsee, K. (2004). Feminism-by-design: Emerging capitalisms, cultural feminism, and women's nongovernmental organizations in postsocialist Eastern Europe. Signs: Journal of Women in Culture and Society, 29(3), 727-753.

Goertz, G., \& Mazur, A. (2008). Mapping gender and politics concepts: Ten guidelines. In G. Goertz \& A. Mazur (Eds.) Politics, gender, and concepts. Theory and methodology (pp. 14-44). Cambridge: Cambridge University Press.

Greskovits, B. (2015). The hollowing and backsliding of democracy in East Central Europe. Global Policy, 6(1), 28-37.

Htun, M., \& Weldon, S. (2012). The civic origins of progressive policy change: Combating violence against women in global perspective, 1975-2005. American Political Science Review, 106(3), 548-569.

Human Rights First. (2017). Poland's new front. A government's war against civil society. Retrieved from http://www.humanrightsfirst.org/sites/default/files/ Poland-Report-August-2017.pdf

Kantola, J., \& Lombardo, E. (2017). Gender and the economic crisis: Politics, institutions and intersectional- ity. Basingstoke: Palgrave Macmillan.

Karamessini, M., \& Rubery, J. (Eds.). (2013). Women and austerity: The economic crisis and the future for gender equality (Vol. 11). New York, NY: Routledge.

Kikas, M. (2016, December 16). A conservative counterrevolution in Croatia. LeftEast. Retrieved from http:// www.criticatac.ro/lefteast/a-conservative-counterre volution-in-croatia

Kovats, E., \& Poim, M. (Eds.). (2015). Gender as symbolic glue. The position and role of conservative and far right parties in the anti-gender mobilizations in Europe. Budapest: FEPS-Foundation for European Progressive Studies.

Krizsan, A., \& Roggeband, C. (2018). The gender politics of domestic violence. Feminists engaging the state in Central and Eastern Europe. New York, NY: Routledge.

Krizsan, A., \& Zentai, V. (2017). Policy paper summarizing findings on backsliding in equality policies and inclusion measures addressing gender, disability and ethnicity based inequalities. In N. Sitter, A. Batory, A. Krizsan, \& V. Zentai (Eds.), Backsliding in area of constitutional safeguards and independent institutions, corruption control, and general equality and minorities. Budapest: Central European University. Retrieved from http://www.transcrisis.eu/wp-content/ uploads/2017/05/D6.2-Backsliding-in-area-of-consti tutional-safeguards-and-independent-institutions-cor ruption-control-and-general-equality-and-minorities $-1 . p d f$

Kuhar, R. (2015). Playing with science: Sexual citizenship and the Roman Catholic Church counter-narratives in Slovenia and Croatia. Women's Studies International Forum, 49, 84-92.

Kuhar, R., \& Paternotte, D. (2017). Anti-gender campaigns in Europe: Mobilizing against equality. London: Rowman \& Littlefield International.

Lombardo, E., Meier, P., \& Verloo, M. (Eds.). (2009). The discursive politics of gender equality. Stretching, bending and policy-making. London: Routledge.

Mamula, M., Vukmanić, M., Zore, P., Stanić, D., \& Hojt, A. (2010). Organizacije civilnog drustva koje pružaju specijalizirane servise ženama žrtvama nasilja kao ključni akteri u procesu demokratizacije društva [Civil society organizations that provide specialized services to women victims of violence as key actors in the process of democratization of society]. Zagreb, Croatia: Women's Room.

Manjoo, R. (2013). Report of the special rapporteur on violence against women, its causes and consequences. Mission to Croatia (A/HRC/23/49/Add.4). New York, NY: Human Rights Council. Retrieved from http:// www.ohchr.org/Documents/HRBodies/HRCouncil/Reg ularSession/Session23/A-HRC-23-49-Add-4_en.pdf

McBride, D. E., \& Mazur, A. (2010). The politics of state feminism: Innovation in comparative research. Philadelphia, PA: Temple University Press.

Minnesota Advocates for Human Rights, Autonomous 
Women's House Zagreb, \& Bulgarian Gender Research Foundation. (2012). Implementation of Croatia's domestic violence legislation. A human rights report. Minneapolis: The Advocates for Human Rights. Retrieved from http://www.theadvocatesforhuman rights.org/uploads/croatia_final_report_2012.pdf

Norris, P. (2016, March 11) It's not just Trump: Authoritarian populism is rising across the west. Here's why. The Washington Post. Retrieved from https://www. washingtonpost.com/news/monkey-cage/wp/2016/ 03/11/its-not-just-trump-authoritarian-populism-isrising-across-the-west-heres-why/?noredirect=on\& utm_term $=.1 \mathrm{a} 5 \mathrm{cb} 823278 \mathrm{c}$

Pitkin, H. F. (1967). The concept of representation. Berkley, CA: University of California Press.

Popa, R. (2015). A decade-long struggle for change: Women's mobilization and domestic violence legal and policy reform in Romania. In A. Krizsan (Ed.), Mobilizing for policy change: Women's movements in central and eastern European domestic violence policy struggles (pp. 185-222). Budapest: Central European University. Retrieved from https://cps.ceu.edu/ sites/default/files/publications/cps-book-womensmovements-in-cee-2015.pdf

Rutzen, D. (2015). Civil society under assault. Journal of Democracy, 26(4), 28-39.

Selewa, D. (2016). The policy on gender equality in Poland-Update September 2016. Strasbourg, France: European Parliament. Retrieved from http:// www.europarl.europa.eu/RegData/etudes/STUD/20 16/571372/IPOL_STU(2016)571372_EN.pdf

Stratigaki, M. (2005). The co-optation of gender concepts in EU policies: The case of reconciliation of work and family. Social Politics: International Studies in Gender, State \& Society, 11(1), 30-56.

Stubbs, P. (2016). Croatian parliament rejects Ombudsperson for children's rights report (ESPN Flash Report 2016/30). Brussels, Belgium: European Commission. Retrieved from http://ec.europa.eu/ social/home.jsp?langld=en

Tarrow, S. G., \& Petrova, T. (2007). Transactional and participatory activism in the emerging European polity: The puzzle of East-Central Europe. Comparative Political Studies, 40(1), 74-94.

TASZ. (2016). A norvég civil támadások a NER-ben [Attacks on the Norwegian civil fund in the regime of national cooperation]. TASZ. Retrieved from http://ataszjelenti.blog.hu/2016/04/08/a_norveg_ civil_tamadasok_a_ner-ben

Taylor, V. (1989). Social movement continuity: The women's movement in abeyance. American Sociological Review, 54(5), 761-775.

Tilly, C. (2007). Democracy. New York, NY: Cambridge University Press.

The Guardian. (2017, October 5). Police raid offices of women's groups in Poland after protests. The Guardian. Retrieved from https://www.theguardian. com/world/2017/oct/05/police-raid-offices-of-wo mens-groups-in-poland

Van Dyke, N., \& McCammon, H. (Eds). (2010). Strategic alliances: New studies of social movement coalitions. Minneapolis, MN: University of Minnesota Press.

Verloo, M. (Ed.). (2018). Varieties in opposition to gender equality in Europe. New York, NY: Routledge.

Walby, S. (2015). Crisis. Cambridge: Polity Press.

\section{About the Authors}

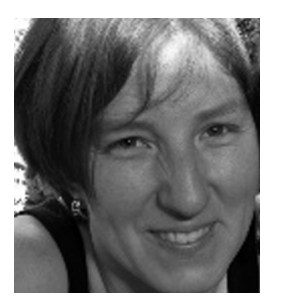

Andrea Krizsán is a Research Fellow at the Center for Policy Studies, Central European University, Budapest, Hungary. Her research focuses on the comparative politics of gender inequality, violence against women and intersectionality in Central and Eastern Europe.

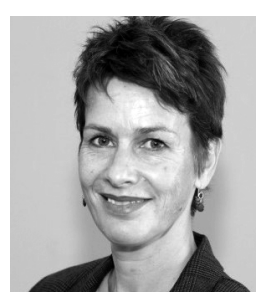

Conny Roggeband lectures at the Department of Political Science of the University of Amsterdam. Her research interests include gender mainstreaming and equality policies, gender-based violence, social movements, and transnational feminist networking. 